\title{
Four statuses of adulthood: adult roles, psychosocial maturity and identity formation in emerging adulthood
}

\section{BACKGROUND}

The main aim of the study was to identify differences pertaining to sense of adulthood, exploration, and commitment dimensions between groups of subjects differing in respect of the number of fulfilled adulthood roles and the level of psychosocial maturity.

\section{PARTICIPANTS AND PROCEDURE}

Participants were 358 individuals aged 18 to 30 . Four groups of individuals with different adulthood statuses were designated: (1) immature non-adults (low psychosocial maturity, a small number of adult roles), (2) immature adults (low psychosocial maturity, a large number of adult roles), (3) mature non-adults (high psychosocial maturity, a small number of adult roles), (4) mature adults (high psychosocial maturity, a large number of adult roles).

\section{RESULTS}

In the two groups characterized by a high level of psychosocial maturity, sense of adulthood proved to be higher than in the other two groups. Immature adults manifest- ed more visible signs of identity crisis than mature adults, and the pattern of the results in the former group was similar to that observed in the group of immature non-adults and mature non-adults.

\section{CONCLUSIONS}

The studies offer an insight into the relationship between identity of individuals entering adulthood, and social and personal determinants of its formation. The simultaneous analysis of selected psychological and contextual conditionings of identity formation enabled us to obtain valuable results that allow us to formulate the conclusion that both of the spheres mentioned above are important for identity development, and that the most favorable option for identity formation in different areas of young adults' functioning is the joint development of both psychosocial maturity and adult roles.

\section{KEY WORDS}

commitment; exploration; psychosocial maturity; sense of adulthood; social roles of adulthood; status of adulthood

ORganizations - 1: Educational Research Institute, Warsaw, Poland · 2: Institute of Psychology, Adam Mickiewicz University, Poznan, Poland · 3: Warsaw, Poland

AUthors' CONTRIBUtion - A: Study design - B: Data collection - C: Statistical analysis - D: Data interpretation .

E: Manuscript preparation - F: Literature search · G: Funds collection

CORResponding AUthor - Konrad Piotrowski, Ph.D., Educational Research Institute, Early Childhood Education and Care Research Unit, 8 Górczewska Str., 01-180 Warsaw, Poland, e-mail: k.piotrowski@ibe.edu.pl

to Cite this ARTICLE - Piotrowski, K., Brzezińska, A.I. \& Pietrzak, J. (2013). Four statuses of adulthood: adult roles, psychosocial maturity and identity formation in emerging adulthood. Health Psychology Report, 1, 52-62.

DOI: $10.5114 /$ hpr.2013.40469 


\section{BACKGROUND}

\section{ADULTHOOD FROM THE OBJECTIVE AND SUBJECTIVE PERSPECTIVE}

When defining the notion of adulthood and indicating the criteria on the basis of which a person can be considered an adult, one can refer to the age range in which this phase is supposed to start. Determining adulthood in terms of achieving a particular age, while effective in legal systems, seems to be unsatisfactory in psychological studies. The gradual divergence of societies from patterns of functioning based on stable, often hereditary, social roles has contributed to the fact that nowadays the age criterion has ceased to be considered a good marker of an individual's life situation (Shanahan, 2000).

When describing adulthood, sociologists emphasize the importance of undertaking and executing social roles typical of an adult individual in a given society (Hogan \& Astone, 1986). Whether a person can be recognized as an adult depends on the scope and manner in which these social roles are undertaken. In this context, the most frequently mentioned roles of adulthood are: professional roles, associated with finishing education and beginning full-time work; and family roles, connected with leaving the family home, establishing an independent household, building a stable relationship, and having children. One way of evaluating the location of an individu$\mathrm{al}$ on the dimension of adulthood, understood as the attainment of roles typical of this period, is building a quantitative marker that expresses the number of roles already undertaken by a person (Reitzle, 2006). This is based on an assumption that the more adult roles that have been undertaken, the more "adult" the person is.

One may also distinguish an approach that treats adulthood as a subjective category (Arnett \& Galambos, 2003; Brzezińska \& Piotrowski, 2010a; Côté, 1997; Piotrowski, 2013), associated with, among others, sense of adulthood, i.e. a conviction of being an adult (categorical approach - e.g. Arnett, 2000), or being an adult to a certain extent (dimensional approach e.g. Luyckx, Schwartz, Goossens \& Pollock, 2008a). This approach also recognizes psychosocial maturity (Greenberger \& Steinberg, 1986), which is expressed by the possession of competences considered typical of adults, including mainly: independence/autonomy (Arnett, 2000; Galambos \& Tilton-Weaver, 2000 ), readiness and an ability to build close, intimate relationships (Brzezińska \& Piotrowski, 2010a; Montgomery, 2005), or marriage readiness (Caroll et al., 2009). Psychosocial maturity expresses, thus, the capacity of a person to function satisfactorily in the adult world, both from the perspective of the person and from the perspective of his or her environment.

\section{PSEUDOMATURITY IN ADOLESCENCE}

Such authors as Shanahan, Porfeli, Mortimer and Erikson (2005) and Johnson, Berg and Sirtozki (2007) have demonstrated that a useful model for identity development analysis is the confluence model that stipulates that identity is based on two pillars: social roles of adulthood and psychosocial maturity or, using a wider category, personal qualities. The idea to analyze both of these constructs jointly is also present in works of such researchers as Greenberger and Steinberg (1986), Galambos and colleagues (Galambos, Barker \& Tilton-Weaver, 2003; Galambos \& Tilton-Weaver, 2000) or Newcomb (1986), who claim that among adolescents one can sometimes observe pseudomature individuals. Such individuals execute certain roles characteristic of adults (e.g. they work, become sexually active) and show, at the same time, a low level of psychological maturity.

Galambos and Tilton-Weaver (2000) investigated 10-18-year-old adolescents among whom pseudomature (called adultoid) individuals were identified. These subjects possessed a sense of being older than their chronological age (older subjective age), had low psychosocial maturity and manifested high problem behaviors. As opposed to mature and immature individuals, they were characterized by an accelerated puberty, which indeed made them look older than their peers, the highest frequency of time spent with peers, and the greatest intensification of conflicts with their mothers. In studies conducted on students, Jordyn and Byrd (2003) demonstrated, in turn, that living independently during the period of emerging adulthood and, at the same time, possessing the moratorium identity status (Marcia, 1966, 1980), was connected with less frequently asking for help from family members in difficult situations than was the case of individuals with other identity statuses. The authors claim that the moratorium status and associated emotional problems observed in their studies (e.g. high level of social mistreatment, alienation from the academic environment, low level of vitality, high level of anxiety and depression) lead to an overall decrease in social activity. At the same time, the physical distance from the family members additionally hampers the obtaining of support. They found that the most adaptive configuration of features was observed in the group of subjects with the identity achievement status. Physical independence from the family of origin during the transition to adulthood does not seem to be the best option for everybody, and undertaking a particular adult role may require achieving a certain level of psychological development. It ought to be stressed that Jordyn and Byrd (2003) investigated young individuals (19-20 years old) who at the time of the investigation were studying. It is possible that this might have been the reason why independent living
Four statuses of adulthood 
resulted in difficulties in their psychosocial functioning.

\section{THEORETICAL APPROACHES TO IDENTITY}

In the studies reported in the present article, identity was analyzed in relation to two constructs. The first one was personal identity - the construct central to the approach initiated by Marcia (1966) and developed in recent years by Luyckx et al. (2008b) to describe in a more detailed manner the two dimensions distinguished by Marcia: exploration and commitment. Beside exploration in breadth, which they defined in line with Marcia's view, as the focus on learning about diverse alternative ways of functioning and experimenting with lifestyles, the authors also distinguished exploration in depth, i.e. evaluation of undertaken identity commitments in order to verify their compliance with personal standards and expectations, and ruminative exploration. The last one is a maladaptive component of the exploration process, and expresses personal fears about the direction in which life is headed. It is connected with difficulties in making identity commitments. Apart from the three dimensions of exploration, the model of Luyckx et al. distinguishes also two dimensions of commitment: commitment making and identification with commitment. In this work, in addition to personal identity, we also analyzed the adult identity (Côté, 1997; Luyckx et al., 2008b), understood as a subjective sense of adulthood.

\section{HYPOTHESES}

In one of our previous works (Piotrowski et al., 2014 - in prep.), prepared on the basis of the same studies, we presented a model according to which psychosocial maturity is a mediator between undertaking adult roles and changes in identity. According to our results, when consecutive adulthood roles are undertaken psychosocial maturity increases, which directly influences identity changes. In this work we also anticipated that among young people transitioning to adulthood there would also be individuals in the case of whom a large number of fulfilled roles of adulthood would coincide with low psychosocial maturity. In other words, we anticipated that it would be possible to distinguish individuals who were described by Greenberger and Steinberg (1986) as pseudomature. Regarding these individuals, one may expect either very strong, inflexible identity commitments in the situation of strong internalization of roles or, on the contrary, identity diffusion. The results of studies conducted by Galambos and Tilton-Weaver (2000) and Jordyn and Byrd (2003) may suggest that the latter option is more probable. We also assumed that the location of a person on the dimensions of adulthood roles and psychosocial maturity would be the factor responsible for differences in levels of identity dimensions (adult identity, exploration, commitments) between subjects of similar biological age. The aim of the study conducted by our team was to verify these predictions. To our knowledge, this is the first work in which the issue of pseudomaturity has been applied to individuals who have already completed their education.

\section{PARTICIPANTS AND PROCEDURE}

In the present study, 358 individuals between the age of 18 and $30(M=22.48 ; S D=3.59)$ took part. Among the subjects, there were: (1) secondary school students $(n=142 ; 39.7 \%$ of the sample; $M=18.70$; $S D=0.62)$, (2) full-time university students $(n=109$; $30.4 \%$ of the sample; $M=23.52 ; S D=1.82$ ) and (3) individuals who had already finished education, both in full- and part-time mode ( $n=107 ; 29.9 \%$ of the sample; $M=26.42 ; S D=1.89)$. The last group consisted mainly of individuals with higher education $(n=91 ; 85 \%$ of the subjects); individuals with only secondary education were in the minority ( $n=16 ; 15 \%$ of the subjects). The majority of investigated individuals were, in their own opinion, in a quite good financial situation: $64.5 \%$ of the participants $(n=231)$ said that they could afford most of what they wanted without having to deny themselves much, whereas $22.6 \%$ of the subjects $(n=81)$ said that they could afford most things thanks to being thrifty. The percentage of individuals who responded that their income was insufficient to meet some of their everyday needs was $12.8 \%(n=46)$. A little more than half of the whole sample $(n=204$; $57 \%$ ) had a partner (including: informal relationships: $n=177$ [86.8\%]; marriage: $n=27$ [13.2\%]), and $7.5 \%$ $(n=27)$ had at least one child. The percentage of subjects who lived with their parents was $56 \%(n=202)$, whereas participants who at the time of the study lived separately from their families (with a group of peers, alone, or with a partner) constituted $44 \%$ of the sample $(n=156)$. At the time of the study, $38 \%$ of the participants worked either full- or part-time; the rest of the sample was not involved in any professional activity. The subjects were recruited in urban public secondary schools, universities, and various companies. The subjects who at the time of the study were pupils or students were, for the most part, investigated in the educational institutions they attended.

\section{MEASURES}

Psychosocial maturity. In the reported studies the Independence and Intimacy Scale (Piotrowski, 2013), which allows for a rating of participants on two dimensions of psychosocial maturity, sense of inde- 
pendence and intimacy (Galambos, Magill-Evans \& Darrah, 2008), was used. The former dimension expresses the degree to which a person considers himor herself responsible for his or her actions, makes independent decisions, and is independent from other people (6 items, e.g. I myself decide which actions to engage in). This dimension is similar to the individualistic criteria postulated by Arnett (2000). The latter dimension - intimacy - describes the degree to which the person considers him- or herself to be ready to engage in and maintain a close, intimate relationship with a partner (3 items, e.g. I am ready for a long-term commitment to one partner). All of the items were assessed by the subject on a 6-point Likert scale, where 1 stood for definitely not, and 6 for definitely yes. Cronbach's alpha coefficients for the two scales were, respectively, 0.70 and 0.81 . In the presented analysis we used a general indicator of psychosocial maturity - the mean result of all items of the scale. The alpha reliability coefficient for this indicator was 0.77 .

Social roles of adulthood. By means of determining the location of the investigated subjects on the dimension of adulthood roles, a summary, quantitative indicator was created. The indicator defined the number of roles, out of the analyzed pool, the subjects fulfilled: (1) building a close, intimate relationship (having a partner: being married or in an open relationship $=1$; lack of a partner $=0$ ), (2) running an independent household (living outside of the family home, i.e. with peers, alone, or with a partner $=1$; living with parents $=0$ ), (3) having children (having at least one child $=1$; not having children $=0$ ), (4) commencing a professional career (working $=1$; not working $=0$ ), (5) finishing education (not studying in any kind of educational institution $=1$; being a full- or part-time pupil/student $=0$ ). The result of such an approach was the creation of a variable that ranged from 0 - does not fulfill any adult roles, to 5 - fulfills all of the analyzed adult roles.

Personal identity dimensions. The Polish adaptation (Brzezińska \& Piotrowski, 2009; 2010b) of the Dimensions of Identity Development Scale (DIDS; Luyckx et al., 2008b) was applied in order to measure personal identity dimensions: (1) exploration in breadth: the extent to which a person is looking for various alternatives in relation to personal goals, values, and beliefs (e.g. I think actively about the direction I want to take in my life); (2) exploration in depth: thorough evaluation of the decisions and choices already made, or of undertaken commitments, in order to determine the extent to which they meet personal standards (e.g. I actively consider whether the future plans I strive for correspond to what I really want); (3) ruminative exploration: the intensity of an individual's concerns and problems that occur when the person engages in areas important for his or her identity development (e.g. I am doubtful about what I really want to achieve in life); (4) commitment making: the degree to which adolescents have made choices about important identity issues (e.g. I have decided on the direction I want to follow in my life); and (5) identification with commitment: the degree to which the person identifies with the choices and commitments he or she has made (e.g. My plans for the future match my true interests and values). All items of the scale, five for each dimension, pertain to the degree to which the subjects have shaped the vision of their future and the vision of themselves in the future. The subjects assessed the items using a 6-point Likert scale, where 1 stood for definitely not, and 6 for definitely yes. Cronbach's alpha coefficients for the five subscales were, respectively, 0.75 , $0.60,0.79,0.87$, and 0.76 .

Adult identity/sense of adulthood. Sense of adulthood was measured using the Polish version of the Adult Identity Resolution Scale (Piotrowski, 2013). It is one of the scales of the Identity Stage Resolution Index (ISRI) developed by Côté (1997). This scale consists of three statements pertaining to the subjective conviction about being an adult (e.g. You consider yourself to be an adult), evaluated on a 6-point scale, from 1 - definitely not, to 6 - definitely yes. Cronbach's alpha coefficient for the whole scale in the investigated sample was 0.81 .

\section{RESULTS}

\section{CORRELATIONAL ANALYSES}

In Table 1, the results of correlational analysis between the variables are presented. Biological age correlated positively ( $r=0.73$ ) with the number of fulfilled adult roles and also, though to a lesser extent, with psychosocial maturity and sense of adulthood. Age proved to be negatively correlated with all three dimensions of exploration. A significant, positive correlation was observed between age and commitment making, although this relationship was weak $(r=0.12)$. The number of adult roles correlated positively with the level of psychosocial maturity $(r=$ $=0.32)$ and sense of adulthood $(r=0.32)$, and negatively with all dimensions of exploration. Dimensions of psychosocial maturity and sense of adulthood were positively connected with one another $(r=0.48)$, and they also positively correlated with the two dimensions of identity commitments, and negatively with ruminative exploration.

The direction and strength of relationships between particular identity dimensions were comparable to those obtained in different studies (Brzezińska \& Piotrowski, 2010a, 2010b; Brzezińska et al. 2010; Luyckx et al., 2008a). The dimensions of exploration (in breadth, in depth, and ruminative) were positively related to one another. The same applied to the two
Four statuses of adulthood 
Table 1

Correlations between variables $(N=358)$

\begin{tabular}{lcccccccc}
\hline Variables & 2 & 3 & 4 & 5 & 6 & 7 & 8 & 9 \\
\hline Age & $0.73^{* * *}$ & $0.22^{* * *}$ & $0.33^{* * *}$ & $-0.24^{* * *}$ & $-0.27^{* * *}$ & $-0.23^{* * *}$ & $0.12^{*}$ & 0.08 \\
Number of adult roles & - & $0.32^{* * *}$ & $0.32^{* * *}$ & $-0.25^{* * *}$ & $-0.26^{* * *}$ & $-0.23^{* * *}$ & $0.12^{*}$ & 0.10 \\
Psychosocial maturity & & - & $0.48^{* * *}$ & -0.01 & 0.04 & $-0.15^{* *}$ & $0.15^{* *}$ & $0.21^{* * *}$ \\
Sense of adulthood & & & - & -0.06 & -0.03 & $-0.18^{* *}$ & $0.20^{* * *}$ & $0.27^{* * *}$ \\
Exploration in breadth & & & - & $0.72^{* * *}$ & $0.48^{* * *}$ & -0.06 & 0.04 \\
Exploration in depth & & & & - & $0.36^{* * *}$ & 0.06 & $0.19^{* * *}$ \\
Ruminative exploration \\
$\begin{array}{l}\text { Commitment making } \\
\text { Identification with } \\
\text { commitment }\end{array}$
\end{tabular}

dimensions of commitment. Ruminative exploration correlated with commitment dimensions negatively. A positive correlation was also observed between exploration in depth and identification with commitments. Generally speaking, the strength of the majority of the analyzed relationships ranged from weak to moderate.

\section{STATUSES OF ADULTHOOD}

In the first step, groups of individuals characterized by different locations on the adulthood dimension, defined from the perspective of the number of fulfilled adult roles and the level of psychosocial maturity, were distinguished. The whole sample was divided according to the median of the number of fulfilled roles of adulthood $(M e=1)$ into two subgroups: (1) with high results (minimum two roles of adulthood fulfilled) and (2) with low results (maximum one role fulfilled). A similar procedure was applied to the general indicator of psychosocial maturity $(M e=4.75)$. Next, both of the two-categorical variables mentioned above were crossed with each other, which resulted in the creation of four groups of subjects (Tables 2 and 3).
Individuals who fulfilled a small number of adulthood roles and, at the same time, were characterized by a low level of psychosocial maturity were defined as immature non-adults (35.2\%). The next group constituted mature non-adults $(20.4 \%)$ - i.e. people who were characterized by a rather small number of the fulfilled social roles of adulthood and who showed high psychosocial maturity. In the group of subjects who fulfilled a large number of adulthood roles, two subgroups were distinguished: immature adults (14.8\% of the sample), who manifested low psychosocial maturity, and mature adults (29.6\% of the sample), who showed high psychosocial maturity. The four homogeneous subgroups distinguished in this way enabled the explanation of $67 \%$ of the variance of psychosocial maturity and $75 \%$ of the variance of the number of adult roles.

\section{SOCIODEMOGRAPHIC CHARACTERISTICS OF THE STATUSES OF ADULTHOOD}

Significant differences in respect of age $(F(3,354)=$ $\left.=172.91 ; p<0.001 ; \eta^{2}=0.59\right)$ were observed between the four identified groups of subjects. Immature nonadults $(M=20.13 ; S D=2.42)$ and mature non-adults

Table 2

Adulthood statuses in the investigated sample

\begin{tabular}{lccc}
\hline \multirow{2}{*}{ Adulthood indicators } & Low & Psychosocial maturity \\
\cline { 3 - 3 } & Small & immature non-adults & mature non-adults \\
$\begin{array}{c}\text { Number of social roles } \\
\text { of adulthood }\end{array}$ & & $n=126 ; 35.2 \%$ of the sample & $n=73 ; 20.4 \%$ of the sample \\
& Large & $n=53 ; 14.8 \%$ of the sample & $n=106 ; 29.6 \%$ of the sample \\
\hline
\end{tabular}


Table 3

Psychosocial maturity and the number of adult roles, and adulthood status

\begin{tabular}{|c|c|c|c|c|c|}
\hline Variables & $\begin{array}{l}\text { Immature } \\
\text { non-adults }\end{array}$ & $\begin{array}{c}\text { Mature } \\
\text { non-adults }\end{array}$ & $\begin{array}{l}\text { Immature } \\
\text { adults }\end{array}$ & $\begin{array}{l}\text { Mature } \\
\text { adults }\end{array}$ & $F\left(\eta^{2}\right)$ \\
\hline Psychosocial maturity & $\begin{aligned} M & =4.16^{\mathrm{a}} \\
S D & =0.51\end{aligned}$ & $\begin{aligned} M & =5.28^{\mathrm{c}} \\
S D & =0.24\end{aligned}$ & $\begin{aligned} M & =4.36^{\mathrm{b}} \\
S D & =0.32\end{aligned}$ & $\begin{aligned} M & =5.31^{\mathrm{c}} \\
S D & =0.31\end{aligned}$ & $\begin{array}{l}239.90^{* * *} \\
(0.67)\end{array}$ \\
\hline $\begin{array}{l}\text { Average number of fulfilled } \\
\text { roles of adulthood }\end{array}$ & $\begin{aligned} M & =0.60^{\mathrm{a}} \\
S D & =0.49\end{aligned}$ & $\begin{aligned} M & =0.64^{\mathrm{a}} \\
S D & =0.48\end{aligned}$ & $\begin{aligned} M & =3.14^{\mathrm{b}} \\
S D & =0.90\end{aligned}$ & $\begin{aligned} M & =3.21^{\mathrm{c}} \\
S D & =0.99\end{aligned}$ & $\begin{array}{l}356.59^{* * *} \\
(0.75)\end{array}$ \\
\hline
\end{tabular}

Note. Different indexes next to the mean values stand for significant differences between the groups (post-hoc: Tukey HSD test) *** $p<0.001$

$(M=19.79 ; S D=2.28)$ were significantly younger than immature adults $(M=25.60 ; S D=2.29)$ and mature adults $(M=25.55 ; S D=2.15)$. Individuals classified as immature non-adults and mature non-adults were mainly secondary school pupils and, to a lesser extent, full-time university students (Table 4). No individuals who had already finished education were found in these groups. In turn, the groups of immature adults and mature adults were predominantly composed of individuals who did not study or who, though to a lesser extent, studied full-time.

Due to the method of analysis adopted in the discussed studies, in the two younger groups (non-adults) there were not many people who engaged in the fulfillment of any roles of adulthood. If they did engage in any of them, it was usually connected with having a partner (open relationship). The subjects from the group of immature adults and mature adults fulfilled a large number of the social roles of adulthood, and no significant differences in respect of the type of roles could be observed between them. For the most part, these were individuals who had a partner and worked and, in the case of approximately one-sixth of the subjects, had a child. In these groups, there was quite a large variation in the housing situation. Thus, taking into consideration sociodemographic characteristics, significant similarities were observed between immature non-adults and mature non-adults on the one hand, and between immature adults and mature adults on the other hand.

\section{STATUSES OF ADULTHOOD, SENSE OF ADULTHOOD AND PERSONAL IDENTITY}

Individuals representing particular statuses of adulthood differed significantly from one another in terms of sense of adulthood (one-way ANOVA was applied). The lowest scores were observed in the group of immature non-adults and immature adults. In comparison to these groups, the group of mature nonadults obtained significantly higher results, whereas the highest sense of adulthood was observed in the group of mature adults (Table 5).
In order to analyze differences between the distinguished groups in respect of the subjects' location on particular identity dimensions, multivariate analysis of variance (MANOVA), in which the five identity dimensions were treated as dependent variables, was conducted. The overall multivariate effect turned out to be significant [Wilks' $\lambda=0.85 ; F(15,966)=3.81$; $\left.p<0.001 ; \eta^{2}=0.05\right]$. The results of univariate analyzes, enabling interpretation of the MANOVA outcome, are presented in Table 5. The strength of particular effects was significantly weaker than in the case of sense of adulthood $\left(\eta^{2}\right.$ value ranged from 0.03 to 0.08$)$.

In the case of exploration in breadth, the participants from the group of mature non-adults obtained significantly higher results than immature adults and mature adults. In the dimension of exploration in depth, the results of mature non-adults were significantly higher than in the other three groups which, at the same time, did not differ from one another. When it comes to ruminative exploration, mature adults obtained significantly lower results than the subjects from the other groups. Additionally, mature adults obtained higher results in the dimensions of commitment making and identification with commitment in comparison to immature non-adults and immature adults. Mature non-adults did not differ from other groups in those dimensions.

\section{DISCUSSION}

In the studies discussed in this paper, the authors approach the issue of adulthood with a wide perspective. To this end, both the number of undertaken roles of adulthood and the level of psychosocial maturity of the subjects, which consisted here of their sense of independence and readiness to build close intimate relationships, were analyzed. These characteristics were deemed crucial for an analysis of the determinants of sense of adulthood and personal identity. 
Table 4

Adulthood status and sociodemographic characteristics

\begin{tabular}{|c|c|c|c|c|}
\hline Variables & $\begin{array}{l}\text { Immature } \\
\text { non-adults }\end{array}$ & $\begin{array}{c}\text { Mature } \\
\text { non-adults }\end{array}$ & $\begin{array}{l}\text { Immature } \\
\text { adults }\end{array}$ & $\begin{array}{l}\text { Mature } \\
\text { adults }\end{array}$ \\
\hline \multicolumn{5}{|c|}{ Educational situation } \\
\hline Secondary school students & $\begin{array}{c}n=84 \\
(66.7 \%)\end{array}$ & $\begin{array}{c}n=57 \\
(78.1 \%)\end{array}$ & $\begin{array}{c}n=1 \\
(1.9 \%)\end{array}$ & $n=0$ \\
\hline $\begin{array}{l}\text { Full-time university } \\
\text { students }\end{array}$ & $\begin{array}{c}n=42 \\
(33.3 \%)\end{array}$ & $\begin{array}{c}n=16 \\
(21.9 \%)\end{array}$ & $\begin{array}{c}n=16 \\
(30.2 \%)\end{array}$ & $\begin{array}{c}n=35 \\
(33.0 \%)\end{array}$ \\
\hline Non-students & $n=0$ & $n=0$ & $\begin{array}{c}n=36 \\
(67.9 \%)\end{array}$ & $\begin{array}{c}n=71 \\
(67.0 \%)\end{array}$ \\
\hline \multicolumn{5}{|c|}{ Marital status } \\
\hline Does not have a partner & $\begin{array}{c}n=75 \\
(59.5 \%)\end{array}$ & $\begin{array}{c}n=34 \\
(46.6 \%)\end{array}$ & $\begin{array}{c}n=19 \\
(35.8 \%)\end{array}$ & $\begin{array}{c}n=26 \\
(24.5 \%)\end{array}$ \\
\hline $\begin{array}{l}\text { In an informal/open } \\
\text { relationship }\end{array}$ & $\begin{array}{c}n=51 \\
(40.5 \%)\end{array}$ & $\begin{array}{c}n=39 \\
(53.4 \%)\end{array}$ & $\begin{array}{c}n=23 \\
(43.4 \%)\end{array}$ & $\begin{array}{c}n=64 \\
(60.4 \%)\end{array}$ \\
\hline Married & $n=0$ & $n=0$ & $\begin{array}{c}n=11 \\
(20.8 \%)\end{array}$ & $\begin{array}{c}n=16 \\
(15.1 \%)\end{array}$ \\
\hline \multicolumn{5}{|c|}{ Living situation } \\
\hline Lives with parents & $\begin{array}{l}n=109 \\
(86.5 \%)\end{array}$ & $\begin{array}{c}n=65 \\
(89.0 \%)\end{array}$ & $\begin{array}{c}n=10 \\
(18.9 \%)\end{array}$ & $\begin{array}{c}n=18 \\
(17.0 \%)\end{array}$ \\
\hline Lives with peers & $\begin{array}{l}n=11 \\
(8.7 \%)\end{array}$ & $\begin{array}{l}n=5 \\
(6.8 \%)\end{array}$ & $\begin{array}{c}n=13 \\
(24.5 \%)\end{array}$ & $\begin{array}{c}n=27 \\
(25.0 \%)\end{array}$ \\
\hline Lives alone & $\begin{array}{c}n=6 \\
(4.8 \%)\end{array}$ & $\begin{array}{c}n=3 \\
(4.1 \%)\end{array}$ & $\begin{array}{c}n=11 \\
(20.8 \%)\end{array}$ & $\begin{array}{c}n=13 \\
(12.3 \%)\end{array}$ \\
\hline Lives with a partner & $n=0$ & $n=0$ & $\begin{array}{c}n=19 \\
(35.8 \%)\end{array}$ & $\begin{array}{c}n=48 \\
(45.3 \%)\end{array}$ \\
\hline
\end{tabular}

Having children

\begin{tabular}{|c|c|c|c|c|}
\hline Does not have children & $n=126(100.0 \%)$ & $n=73(100.0 \%)$ & $\begin{array}{c}n=45 \\
(84.9 \%)\end{array}$ & $\begin{array}{c}n=87 \\
(82.1 \%)\end{array}$ \\
\hline Has a child/children & $n=0$ & $n=0$ & $\begin{array}{c}n=8 \\
(15.1 \%)\end{array}$ & $\begin{array}{c}n=19 \\
(17.9 \%)\end{array}$ \\
\hline \multicolumn{5}{|c|}{ Professional career } \\
\hline Does not work & $n=115(93.5 \%)$ & $n=73(100.0 \%)$ & $\begin{array}{c}n=8 \\
(15.1 \%)\end{array}$ & $\begin{array}{c}n=24 \\
(22.6 \%)\end{array}$ \\
\hline Works & $\begin{array}{c}n=8 \\
(6.5 \%)\end{array}$ & $n=0$ & $\begin{array}{c}n=45 \\
(84.9 \%)\end{array}$ & $\begin{array}{c}n=82 \\
(77.4 \%)\end{array}$ \\
\hline
\end{tabular}

\section{IMMATURE ADULTHOOD IN THE INVESTIGATED SAMPLE}

Particularly important for us were the results of individuals referred to by some researchers as pseudomature (Galambos \& Tilton-Weaver, 2000; Greenberger \& Steinberg, 1986), and in the present paper labeled immature adults. On the basis of the selected indicators - the number of undertaken roles of adult- hood - they can be assigned the status of an adult. At the same time, however, these individuals manifest low psychosocial maturity, due to which their adulthood status has an ambivalent character. The obtained results are all the more important when we take into consideration the fact that so far no studies analyzing this topic in the group of non-studying individuals have been conducted. In the investigated sample of people between the age of 18 and 30, 
Table 5

Adulthood status and age, sense of adulthood, and identity dimensions: the results of univariate analysis (post-hoc: Tukey HSD test)

\begin{tabular}{|c|c|c|c|c|c|}
\hline Variables & $\begin{array}{c}\text { Immature } \\
\text { non-adults } \\
n=131\end{array}$ & $\begin{array}{c}\text { Mature } \\
\text { non-adults } \\
n=90\end{array}$ & $\begin{array}{l}\text { Immature } \\
\text { adults } \\
n=48\end{array}$ & $\begin{array}{l}\text { Mature } \\
\text { adults }\end{array}$ & $F\left(\eta^{2}\right)$ \\
\hline Sense of adulthood & $\begin{aligned} M & =3.65^{\mathrm{a}} \\
S D & =0.81\end{aligned}$ & $\begin{aligned} M & =4.21^{\mathrm{b}} \\
S D & =0.88\end{aligned}$ & $\begin{aligned} M & =3.79^{\mathrm{a}} \\
S D & =0.86\end{aligned}$ & $\begin{aligned} M & =4.77^{c} \\
S D & =0.79\end{aligned}$ & $\begin{array}{l}38.66^{* * *} \\
(0.25)\end{array}$ \\
\hline $\begin{array}{l}\text { Exploration in } \\
\text { breadth }\end{array}$ & $\begin{aligned} M & =4.35^{\mathrm{a}, \mathrm{b}} \\
S D & =0.72\end{aligned}$ & $\begin{aligned} M & =4.59^{b} \\
S D & =0.64\end{aligned}$ & $\begin{aligned} M & =4.15^{\mathrm{a}} \\
S D & =0.74\end{aligned}$ & $\begin{aligned} M & =4.08^{\mathrm{a}} \\
S D & =0.84\end{aligned}$ & $\begin{array}{l}7.53^{* * *} \\
(0.06)\end{array}$ \\
\hline $\begin{array}{l}\text { Exploration in } \\
\text { depth }\end{array}$ & $\begin{aligned} M & =4.12^{\mathrm{a}} \\
S D & =0.67\end{aligned}$ & $\begin{aligned} M & =4.45^{\mathrm{b}} \\
S D & =0.62\end{aligned}$ & $\begin{aligned} M & =3.89^{\mathrm{a}} \\
S D & =0.79\end{aligned}$ & $\begin{aligned} M & =3.91^{\mathrm{a}} \\
S D & =0.71\end{aligned}$ & $\begin{array}{l}10.69^{* * *} \\
(0.08)\end{array}$ \\
\hline $\begin{array}{l}\text { Ruminative } \\
\text { exploration }\end{array}$ & $\begin{aligned} M & =3.77^{\mathrm{b}} \\
S D & =0.80\end{aligned}$ & $\begin{aligned} M & =3.75^{\mathrm{b}} \\
S D & =0.79\end{aligned}$ & $\begin{aligned} M & =3.59^{\mathrm{b}} \\
S D & =0.80\end{aligned}$ & $\begin{aligned} M & =3.23^{\mathrm{a}} \\
S D & =0.95\end{aligned}$ & $\begin{array}{l}9.02^{* * *} \\
(0.07)\end{array}$ \\
\hline $\begin{array}{l}\text { Commitment } \\
\text { making }\end{array}$ & $\begin{aligned} M & =3.61^{\mathrm{a}} \\
S D & =0.87\end{aligned}$ & $\begin{aligned} M & =3.75^{\mathrm{a}, \mathrm{b}} \\
S D & =0.87\end{aligned}$ & $\begin{aligned} M & =3.70^{\mathrm{a}} \\
S D & =0.92\end{aligned}$ & $\begin{aligned} M & =4.00^{\mathrm{b}} \\
S D & =0.90\end{aligned}$ & $\begin{array}{l}4.90^{* *} \\
(0.04)\end{array}$ \\
\hline $\begin{array}{l}\text { Identification with } \\
\text { commitment }\end{array}$ & $\begin{aligned} M & =4.04^{\mathrm{a}} \\
S D & =0.75\end{aligned}$ & $\begin{aligned} M & =4.18^{\mathrm{a}, \mathrm{b}} \\
S D & =0.66\end{aligned}$ & $\begin{aligned} M & =4.00^{\mathrm{a}} \\
S D & =0.71\end{aligned}$ & $\begin{aligned} M & =4.36^{\mathrm{b}} \\
S D & =0.70\end{aligned}$ & $\begin{array}{l}5.02^{* *} \\
(0.04)\end{array}$ \\
\hline
\end{tabular}

Note. Different indexes next to the mean values stand for significant differences between the groups (post-hoc: Tukey HSD test) ${ }^{* *} p<0.01 ;{ }^{* * *} p<0.001$

immature adults, being on average about 25 years old, constituted a distinct minority (15\%). An analogous phenomenon could be observed in other studies exploring similar issues (Galambos \& Tilton-Weaver, 2000). Over $50 \%$ of the total sample constituted 20 -year-old subjects, who shared a common feature of a rather small (naturally, when compared with the whole sample) engagement in the fulfillment of adulthood roles, although even among them considerable differences in levels of psychosocial maturity were observed (immature non-adults vs. mature non-adults). Among older subjects (of about 25-26 years of age on average), one could also observe individuals whose development in different dimensions of adulthood was to a greater extent synchronized, when compared to immature adults. Such individuals fulfilled a large number of adulthood roles and had, at the same time, high psychosocial maturity.

Between immature adults and mature adults no distinct differences in respect of the number and kind of roles they fulfilled were observed. This suggests that undertaking the social roles of adulthood, although they may have a positive influence on the development of psychosocial maturity (Piotrowski et al., 2014 - in prep.), does not affect this development equally strongly in all cases. Individuals in whom the undertaking of adulthood roles does not lead to an increase of psychosocial maturity, or in whom the roles are undertaken with low maturity, represent the category of very immature adults. In our studies, the number of fulfilled roles of adulthood correlated to a greater extent with age than with psychosocial maturity, which may also suggest that undertaking certain roles is dictated rather by social norms determining the "proper" age for the undertaking of adulthood roles.

\section{STATUS OF ADULTHOOD AND SENSE OF ADULTHOOD}

The subgroups of individuals with different adulthood statuses that were compared by us differed most significantly in terms of sense of adulthood, i.e. locating oneself at a particular point of the non-adult - adult dimension. The lowest results on this dimension were obtained by individuals who were characterized by low psychosocial maturity, regardless of whether they had fulfilled a large or a small number of the social roles of adulthood, that is immature non-adults and immature adults. Particular attention ought to be devoted to the latter group. The sense of adulthood of these individuals was significantly lower in comparison to the five years younger, on average, individuals who showed high psychosocial maturity and yet had only undertaken a small number of adulthood roles (mature non-adults). The individuals who had the strongest sense of adulthood were those who on both analyzed dimensions of adulthood scored high. As our research shows, for the formation of a sense of adulthood what appears to be more important is the personal characteristics of the individual associated with their level of psychosocial maturity. Undertaken adult roles seem to be merely some of the numerous factors determining the for-
Four statuses of adulthood 
mation of maturity (Piotrowski et al., 2014 - in prep.). Psychosocial maturity is understood as a competence that is the result of the person's development as they progress through life. Nevertheless, it seems that for the development of an adult individual's identity the most conducive is synchronization of the development process on each of the dimensions. This seems to be confirmed by the highest sense of adulthood being registered among individuals recognized in our study as mature adults.

Konrad

Piotrowski,

Anna Izabela

Brzezińska, Joanna Pietrzak

\section{STATUS OF ADULTHOOD AND PERSONAL IDENTITY}

The identified subgroups of individuals differed also, although not to such a great extent as in the case of adult identity, in respect of their location on the dimensions of personal identity. In the case of exploration in breadth and exploration in depth, which are favorable to identity changes (Luyckx et al., 2008b), the subjects who had engaged themselves in the fulfillment of a larger number of roles (immature adults and mature adults) obtained lower results than the others. This suggests that undertaken social roles and age, with which the roles are strongly connected, can limit the person's engagement in exploration activities. The identity of such individuals is more stable and less prone to changes. However, in the case of immature adults, in comparison to mature adults, commitment making and identification with commitment turned out to be weaker, and ruminative exploration, which is an indicator of difficulties with identity formation and problems with constructive coping with identity crisis, was stronger. With respect to these dimensions, immature adults were rather more similar to the subjects from the other two subgroups (immature non-adults and mature non-adults), who were, let us stress, on average five years younger. In their case, the sphere of commitment is rather poorly developed, and weak exploration can additionally hamper the future development of this sphere. Fulfilled roles of adulthood can be seen as a barrier for exploration (Yoder, 2000), which, in the case of immature adults, can lead to problems with identity formation.

\section{ADULT ROLES, PSYCHOSOCIAL MATURITY AND IDENTITY IN EMERGING ADULTHOOD}

As we have shown, fulfilling social roles of adulthood is not always conducive to a higher sense of adulthood, and does not always lead to psychological independence or an increase in the degree of one's own responsibility. In such a situation, it can turn out that the fulfillment of adulthood roles not only does not support coping with an identity crisis, but can even constitute a risk factor due to its restraining in- fluence on the scope of exploration. Individuals who are not ready to carry out certain roles of adulthood, which nevertheless they have started to fulfill, either out of necessity or as a consequence of their own decisions, may experience difficulties with identifying with the roles and accepting the rules governing them, which can consequently hinder or even disrupt identity development.

It seems that only in the situation when the two spheres, i.e. the fulfillment of social roles of adulthood and psychosocial maturity, harmonize with each other, which happens either when (a) along with undertaking roles of adulthood changes in psychosocial maturity take place (such a mechanism was found in the investigated sample; see Piotrowski et al., 2014 in prep.) or when (b) the level of psychosocial maturity is high and then the social roles of adulthood are undertaken (Erikson, 1968), one can anticipate a constructive solution to the identity crisis and, as it can be expected, future successful development in other spheres. Naturally, this does not mean that biological age ought to be treated as an insignificant predictor of changes in identity. Even when the influence of adult roles and psychosocial maturity was controlled for, age turned out to be positively, although not very strongly, connected with sense of adulthood of the individuals. Notwithstanding, the results of our study support more the hypothesis about individualized identity formation paths, running, to a certain extent, independently from the person's age, than the hypothesis about a linear character of identity development from its initial diffusion to identity achievement (Marcia, 1966).

An increase of psychosocial maturity during the period of transition from late adolescence to early adulthood and the undertaking of consecutive roles of adulthood can be conducive to building and strengthening the system of commitments with which the person identifies. At the same time, ceasing to carry out roles of adulthood already undertaken (e.g. splitting up with a partner and returning to the parental house) can result in weakening the sense of adulthood, as was demonstrated by the studies of Benson and Furstenberg (2007), and weaken, in all likelihood, the strength of commitments and identification with them. This seems to be in line with the confluence model of Shanahan et al. (2005), according to which identity remains under the influence of both undertaken roles and personal characteristics. Yet, our findings enable us to claim that the influence of these factors is marked by a certain idiosyncrasy, especially when it comes to the fulfillment of adult roles. When undertaking adult roles does not coincide with achieving a certain level of psychosocial maturity, it is not conducive to progressive changes in identity, i.e. an increase in sense of adulthood, and an increase in the number/strength of commitments and identification with them. 


\section{LIMITATIONS AND SUGGESTIONS FOR FUTURE RESEARCH}

First of all, one important limitation of the reported studies was the homogeneity of the investigated sample. The participants were either well-educated young people, or students of secondary school or university, and generally had a good financial situation. This is a serious limitation for generalization of the results. Secondly, the conclusions presented in this paper were based on the results of cross-sectional studies. It would be highly recommended to verify the influence of adult roles and psychosocial maturity in longitudinal studies, and/or in a sample of individuals with a different social, educational, professional or economic status. In our studies, we also did not control for the time that had passed from the beginning of the undertaking of particular social roles, e.g. how long the investigated individual had not studied, or how long the person had not lived in the family home. This may turn out to be a significant factor influencing the research results. Additionally, in the studies under discussion, exclusively data from self-reports were used. In future studies it would be advisable to use different indicators of the investigated variables.

\section{CONCLUSIONS}

The studies offer an insight into the relationship between identity of individuals entering adulthood, and social and personal determinants of its formation. The simultaneous analysis of selected psychological and contextual conditionings of identity formation enabled us to obtain valuable results that allow us to formulate the conclusion that both of the spheres mentioned above are important for identity development, and that the most favorable option for identity formation in different areas of young adults' functioning is the joint development of both psychosocial maturity and adult roles.

\section{REFERENCES}

Arnett, J.J. (2000). Emerging adulthood. A theory of development from the late teens through the twenties. American Psychologist, 55, 469-480.

Arnett, J.J. \& Galambos, N.L. (2003). Culture and conceptions of adulthood. New Directions for Child and Adolescent Development, 100, 91-98.

Benson, J.E. \& Furstenberg, F.F. (2007). Entry into adulthood: are adult role transitions meaningful markers of adult identity? Advances in Life Course Research, 11, 199-224.

Brzezińska, A.I. \& Piotrowski, K. (2009). Diagnoza statusów tożsamości w okresie adolescencji, wy- łaniającej się dorosłości i wczesnej dorosłości za pomocą Skali Wymiarów Rozwoju Tożsamości (DIDS). Studia Psychologiczne, 3, 93-109.

Brzezińska, A.I. \& Piotrowski, K. (2010a). Formowanie się tożsamości a poczucie dorosłości i gotowość do tworzenia bliskich związków. Czasopismo Psychologiczne, 16, 265-274.

Brzezińska, A.I. \& Piotrowski, K. (2010b). Polska adaptacja Skali Wymiarów Rozwoju Tożsamości (DIDS). Polskie Forum Psychologiczne, 15, 66-84.

Brzezińska, A.I., Piotrowski, K., Garbarek-Sawicka, E., Karowska, K. \& Muszyńska, K. (2010). Wymiary tożsamości a ich podmiotowe i kontekstowe korelaty. Studia Psychologiczne, 49, 81-93.

Caroll, J.S., Badger, S., Willoughby, B.J., Nelson, L.J., Madsen, S.D. \& Barry, C.M. (2009). Ready or not? Criteria for marriage readiness among emerging adults. Journal of Adolescent Research, 24, 349-375.

Côté, J.E. (1997). An empirical test of the identity capital model. Journal of Adolescence, 20, 577-597.

Erikson, E.H. (1968). Identity, youth and crisis. New York: Norton.

Galambos, N.L., Barker, E.V. \& Tilton-Weaver, L.C. (2003). Canadian adolescents' implicit theories of immaturity: what does "childish" mean? New Directions for Child and Adolescent Development, 100, 77-89.

Galambos, N.L., Magill-Evans, J. \& Darrah, J. (2008). Psychosocial maturity in the transition to adulthood for people with and without motor disabilities. Rehabilitation Psychology, 53, 498-504.

Galambos, N.L. \& Tilton-Weaver, L.C. (2000). Adolescents' psychosocial maturity, problem behavior, and subjective age: in search of the adultoid. Applied Developmental Science, 4, 178-192.

Greenberger, E. \& Steinberg, L. (1986). When teenagers work: the psychological and social costs of adolescent employment. New York: Basic Books.

Hogan, D.P. \& Astone, N.M. (1986). The transition to adulthood. Annual Review of Sociology, 12, 109130.

Johnson, M.K., Berg, J.A. \& Sirotzki, T. (2007). Differentiation in self-perceived adulthood: extending the confluence model of subjective age identity. Social Psychology Quarterly, 70, 243-261.

Jordyn, M. \& Byrd, M. (2003). The relationship between the living arrangements of university students and their identity development. Adolescence, 38, 267-278.

Luyckx, K.,Schwartz,S.J., Berzonsky,M.D.,Soenens, B., Vansteenkiste, M., Smits, I. \& Goossens, L. (2008b). Capturing ruminative exploration: extending the four-dimensional model of identity formation in late adolescence. Journal of Research in Personality, 42, 58-82.

Luyckx, K., Schwartz, S.J., Goossens, L. \& Pollock, S. (2008a). Employment, sense of coherence and identity formation: contextual and psychological
Four statuses of adulthood 
processes on the pathway to sense of adulthood. Journal of Adolescent Research, 23, 566-591.

Marcia, J.E. (1966). Development and validation of ego - identity status. Journal of Personality and Social Psychology, 3, 551-558.

Marcia, J.E. (1980). Identity in adolescence. In: J. Adelson (ed.). Handbook of adolescent psychology (pp. 159-187). New York: John Wiley and Sons.

Montgomery, M.J. (2005). Psychosocial intimacy and identity: from early adolescence to emerging adul-

Konrad

Piotrowski, Anna Izabela

Brzezińska, Joanna Pietrzak thood. Journal of Adolescent Research, 20, 346-374.

Newcomb, M.D. (1986). Pseudomaturity among adolescents: construct validation, sex differences, and associations in adulthood. Journal of Drug Issues, 26, 477-504.

Piotrowski, K. (2013). Tożsamość osobista w okresie wkraczania w dorostość. Sytuacja młodych osób z ruchowym ograniczeniem sprawności i ich sprawnych rówieśników [Personal identity during the transition to adulthood. Situation of disabled and nondisabled youth]. Wielichowo: TIPI.

Piotrowski, K., Brzezińska, A. \& Luyckx, K. (2014 - in prep.). Adult roles and psychosocial maturity as predictors of identity formation in emerging adulthood: An expansion of the confluence model.

Reitzle, M. (2006). The connections between adulthood transitions and the self-perception of being adult in the changing contexts of East and West Germany. European Psychologist, 11, 25-38.

Shanahan, M.J. (2000). Pathways to adulthood in changing societies: variability and mechanisms in life course perspective. Annual Review of Sociology, 26, 667-692.

Shanahan, M.J., Porfeli, E., Mortimer, J.T. \& Erikson, L.D. (2005). Subjective age identity and the transition to adulthood: when does one become an adult? In: R.A. Settersen, F.F. Furstenberg, R.G. Rumbaut (eds.). On the frontier of adulthood: theory, research, and public policy (pp. 225-255). Chicago: University of Chicago Press.

Yoder, A.E. (2000). Barriers to ego identity status formation: a contextual qualification of Marcia's identity status paradigm. Journal of Adolescence, 23, 95-106. 